\title{
Az Európai Parlament múködése a koronavírus-járvány idején: valódi megoldás-e a távmegoldás?
}

\section{The Functioning of the European Parliament during the Coronavirus Pandemic: Is the Remote Solution a Real Solution?}

Az Európai Parlament eddigi múködése során példa nélküli helyzettel találta magát szemben. A koronavírus-járvány miatt elrendelt közegészségügyi intézkedésekre tekintettel március közepe óta lehetetlenné vált az európai parlamenti képviselők fizikai jelenlétével megtartani a plenáris üléseket. A Parlament a kialakult problémát azzal kivánta áthidalni, hogy egy Elnökségi határozat keretében értelmezte az Eljárási Szabályzat elektronikus szavazásról szóló rendelkezését.

Így jelenleg a Parlament távmúködéssel ülésezik, amire azonban nem rendelkezik megfelelő jogalappal, gyakorlata pedig szembemegy az Eljárási Szabályzattal, amelyet a mai napig sem módositott. A 2020-as évben egyértelmüen nem rendeztek meg 12 plenáris ülést Strasbourgban, ami az EUSZ 6. Jegyzőkönyvének rendelkezései alapján a Parlament kötelezettsége lenne. A témáért felelös parlamenti képviselök hónapok óta alternatívákat keresnek a helyzet megoldása érdekében, a jogszerü müködés helyreállitása azonban akár 2021 tavaszáig is elhúzódhat, miközben a müködéssel szemben támasztható eljárásjogi kifogásokra való tekintettel az Európai Parlament akár az EUMSZ 263. cikke szerinti megsemmisítési keresettel is szembetalálhatja magát.

Kulcsszavak: Európai Parlament, eljárásjog, szavazati jog, plenáris ülés, megsemmisítési kereset, koronavírus

The European Parliament has found itself in an unprecedented position in its operation so far. In view of the public health measures imposed in response to the coronavirus pandemic, it has become impossible since mid-March to hold plenary sessions with the physical presence of MEPs. The Parliament sought to overcome this problem by

Petri Bernadett jogász, politikai tanácsadó, Európai Parlament, kutató, Nemzeti Közszolgálati Egyetem Európa Stratégia Kutatóintézet, e-mail: bernadett.petri@ep.europa.eu 
interpreting a provision in the Rules of Procedure concerning electronic voting in the framework of a Bureau decision.

Thus, the Parliament currently holds sessions by way of telecommunication, for which, however, it does not have an adequate legal basis, and its practice runs counter to the Rules of Procedure, which it has not amended to date. Twelve plenary sessions have definitely not taken place in Strasbourg in 2020, which is the Parliament's responsibility under the provisions of Protocol 6 to the TEU. MEPs responsible for the issue have been looking for alternatives for months, in order to resolve the situation, but it may even drag on until spring 2021 to restore the legitimate functioning, while the European Parliament may even face an action for annulment under Article 263 TFEU on the basis of infringement of procedural requirements.

Keywords: European Parliament, procedural law, voting rights, plenary session, action for annulment, coronavirus

\section{Bevezetés}

A világméretű koronavírus-járvány kitörése óta, 2020 szeptemberében ülésezett volna az Európai Parlament (Európai Parlament, Parlament vagy EP) első alkalommal ismét Strasbourgban, azonban az aktuális járványügyi helyzetre tekintettel erre ismét nem került sor. A koronavírus-járvány kitörése óta megrendezett plenáris ülések során az európai parlamenti képviselők túlnyomó része fizikailag nem jelent meg a plenáris ülésteremben, mivel a plenáris ülés megtartására távolsági müködés keretében került sor. A 2020. szeptemberi ülést hivatalosan Brüsszelben rendezte meg a Parlament, de a gyakorlatban maradt az eddigi távolsági ülésezés és szavazás.

A járvány következtében előállt helyzet vitán felül sajátos, amelyre nézve nincs hatályban különleges szabályozás vagy rendkívüli jogrend - az uniós intézmények múködése ugyanis általában nem ismeri a rendkívüli helyzet vagy a rendkívüli jogrend fogalmát, pusztán a vis maior jogelv ismeretes az uniós esetjogban. Erről az Európai Unió Bíróságának (EUB, Bíróság) megszilárdult ítélkezési gyakorlata, külön jogszabályi definíció hiányában így rendelkezik: „[A] vis maiort képező körülmények elismerésének előfeltétele, hogy a jogalanyok által hivatkozott külső oknak oly mértékben befolyásolhatatlannak és elháríthatatlannak kell lennie, hogy objektíve lehetetlenné kell tennie, hogy az érintett személy teljesíteni tudja kötelezettségeit. [...] a vis maior fogalmát úgy kell érteni, [...] mint olyan rendkívüli és előre nem látható körülményeket, amelyek következményeit a lehető legnagyobb gondosság ellenére sem lehetett elkerülni."1

Amíg azonban a vis maior jogelve általános értelemben felmentést adhat egyes magánjogi kötelezettségek teljesítése alól, amelyeknek külső kényszerítő tényezők hatására nem tudnak eleget tenni a jogalanyok, nyilvánvalóan nem mentesíti az uniós intézményeket az alól a kötelezettségük alól, hogy tevékenységük jogszerűségének

Az EUB C12/92. sz. Edmond Huygen és társai elleni büntetőeljárás, előzetes döntéshozatal iránti kérelem: Hof van Cassatie - Belgium ügyben 1993. december 7-én hozott ítéletének [ECLI:EU:C:1993:914] 31. pontja. 
alátámasztása érdekében egy olyan jogi keretben járjanak el, amely biztosítja a kiszámíthatóságot, a jogbiztonságot és a jogállamiság érvényesülését. Tekintve, hogy az integráció történetében nem fordult még elő a jelenlegi járványhelyzethez hasonló eset, nem áll rendelkezésre olyan jogi alap, amely mentesítené az intézményeket a hatályos normák betartására vonatkozó kötelezettsége alól. Következésképpen, a jelenleg hatályos elsődleges és másodlagos uniós jog a jelen helyzetben is általános érvénnyel alkalmazandó.

Az Európai Unió valamennyi intézményének működése a jogállamiságon kell hogy alapuljon, ${ }^{2}$ amelynek értelmében tevékenységének összhangban kell állnia az Európai Unióról szóló szerződéssel és az Európai Unió múködéséről szóló szerződéssel, amelyeket a tagállamok önkéntesen és demokratikusan fogadtak el. A Szerződések értelmében, az intézmények célja „az Unió értékeinek érvényesítése, célkitűzéseinek előmozdítása, az Unió, valamint polgárai és a tagállamok érdekeinek szolgálata, továbbá az Unió politikái és intézkedései egységességének, eredményességének és folyamatosságának a biztosítása”. ${ }^{3}$ Továbbá: „Az egyes intézmények a Szerződésekben rájuk ruházott hatáskörök határain belül, az ott meghatározott eljárások, feltételek és célok szerint járnak el."4

A jelen elemzés arról kíván átfogó értékelést nyújtani, hogy a jelenlegi meglehetősen ellentmondásos távülésezési módozat megfelel-e ezeknek a kritériumoknak, az Európai Parlament hatályos Eljárási Szabályzatának (Az Európai Parlament szervezetéről és múködéséről szóló szabályzat, amelyet az összes parlamenti képviselő többségének szavazatával fogadnak el és módosítanak, ${ }^{5}$ további megjelölése: Eljárási Szabályzat), illetve hogy a távszavazás során hozott döntések vonatkozásában milyen jogi következménnyel kell szembenézni, különösen ami a határozatok érvényességét érinti.

A jogi kifogások, mint azt látni fogjuk, elsősorban két eredőre vezethetők vissza. Az egyik annak a kérdése, hogy hozhat-e az Európai Parlament saját hatáskörében, a tagállamok hozzájárulása nélkül olyan döntést, amely eltér a plenáris ülések rendjétől, és nem biztosítja annak a Szerződésekből és esetjogból következő kötelezettségének teljesülését, hogy évi 12 plenáris ülésre kerüljön sor Strasbourgban, folyamatos rendszeresség mellett. A másik tényező pedig azzal összefüggésben áll fenn, hogy a Parlament jelenlegi múködése nem áll összhangban saját Eljárási Szabályzatával, amelyet azonban 2020. március óta sem módosított és nem igazított hozzá a kialakult rendkívüli helyzet körülményeihez.

\section{Az EUSZ 6. jegyzőkönyve szerinti kötelezettség és az Európai Parlament jelenlegi ülésezési rendje}

A strasbourgi ülésezésről szóló olykor heves érzelmeket is kiváltó vita mindenki által ismert, és hosszú időre tekint vissza. Az Európai Parlament 2013-as tanulmánya szerint évi 103 millió euró megtakarítást jelentene, ha a Parlament strasbourgi múködését

Európai Unióról szóló szerződés (EUSZ) 2. cikk.

EUSZ 13. cikk (1) bek.

EUSZ 13. cikk (2) bek.

EUMSZ 232. cikkével összhangban.

Európai Tükör 2020/3. 
Brüsszelbe vinnék át. ${ }^{6} \mathrm{Az}$ Európai Számvevőszék elemzésének értelmében a strasbourgi székhellyel kapcsolatos összes kiadás évi 109 millió euróra rúg, a strasbourgi Parlament épületei vitán felül mindösszesen évi 42 napot múködnek. ${ }^{7}$ Azonban mindez nem változtat azon a tényen, hogy az Európai Parlament székhelye Strasbourg, ennek megváltoztatásához valamennyi tagállam hozzájárulása szükséges, Franciaország részéről pedig ez a szándék nyilvánvalóan nem áll fenn.

1992. december 12-én a tagállamok kormányai közös megállapodás keretében elfogadták ${ }^{8}$ az intézmények, valamint egyes testületek és szervezeti egységek székhelyének meghatározásáról szóló edinburghi döntést. Ennek megfelelően az Európai Unióról szóló szerződés (EUSZ) 6. jegyzőkönyvének egyetlen, a fenti határozatba foglalt cikke rendelkezik az intézmények székhelyéről az Európai Unió működéséről szóló szerződés (EUMSZ, az Európai Közösséget létrehozó szerződésből jött létre a Lisszaboni Szerződés eredményeként, meghatározza az unió elveit és célkitűzéseit, valamint mozgásterét a szakpolitikai területein, továbbá rögzíti az uniós intézmények szervezeti és múködési részleteit) 341. cikkére tekintettel: „Az Európai Parlament székhelye Strasbourg, ahol a tizenkét, havonta tartandó plenáris ülésszak zajlik, beleértve a költségvetési ülésszakot is. A további plenáris ülésszakokat Brüsszelben tartják. Az Európai Parlament bizottságai Brüsszelben üléseznek."

$\mathrm{Az}$ Európai Parlamentnek jogában áll saját múködését biztosítani, de kizárólag szigorú normatív keretek szerint. Az Eljárási Szabályzat 155. cikke szerint „[a] Parlament üléseit és bizottsági üléseit a Szerződések rendelkezéseinek megfelelően tartja”. Az EUMSZ 232. cikke lehetővé teszi a Parlament számára, hogy elfogadja saját eljárási szabályzatát, amely alapján meghatározhatja a plenáris ülések hosszát, de ez csak a Szerződésekkel és az EUB ítélkezési gyakorlatával összhangban történhet, mindez tehát egy szigorú korlátozást jelent az Európai Parlament hatáskörének vonatkozásában.

A Bíróság számos ítéletében elemezte és értelmezte ezeket a rendelkezéseket. Összességében a Bíróság azon a véleményen van, hogy a fent említett tagállami hatáskör ugyan nem akadályozhatja a Parlament mindennapi múködését, azonban a döntések azt is kimondták, hogy az ülések, illetve összességében a munkavégzés helyének bármilyen módosítása szerződésmódosításhoz kötött, ennek megfelelően pedig a tagállamok hozzájárulása szükséges hozzá.

1997-ben az EUB úgy határozott, ${ }^{9}$ hogy a tagállamoknak a székhely meghatározására vonatkozó joga azt is jelenti egyúttal, hogy rögzíthetik a Strasbourgban tartandó plenáris ülések számát is. „Tekintettel arra, hogy a Parlamentnek több munkavégzési helye is van, e tekintetben a hatáskör gyakorlása nemcsak a Parlament székhelyének meghatározását jelenti, hanem az arra vonatkozó bennefoglalt hatáskört is, hogy az ott elvégzendő tevékenységekről is döntsenek a tagállamok, ezzel pontosan meghatározva a munkavégzési hely tartalmát.[...] Ebből adódóan a tagállamok kormányainak az volt

Az Európai Parlament adminisztrációjának 2013. augusztusi feljegyzése: „Az Európai Parlament három munkahelyszíne - a többes földrajzi elhelyezkedéséből fakadó környezeti és regionális hatások." Az Európai Parlament müködésének központosítása révén elérhető uniós költségvetési megtakarítások elemzése. Európai Számvevőszék, 2014.

Az EK 216. cikk, az ESZAK 77. cikk és az Euratom-szerződés 189. cikke alapján.

Az EUB C-345/95 sz. Francia Köztársaság kontra Európai Parlament ügyében 1997. október 1.-én hozott ítélete [ECLI:EU:C:1997:450] 
a szándéka, hogy előírják: a Parlament székhelye, Strasbourg legyen a rendes plenáris ülésezés fő helyszíne, és ebből a célból azt is meghatározzák, hogy évente hány plenáris ülést kell ott tartani kötelező jelleggel."10

A Bíróság értékelése szerint az edinburghi döntést úgy kell értelmezni, hogy a Parlament székhelyének meghatározása egyben azt is jelenti, hogy ott megfelelő rendszerességgel 12 rendes plenáris ülést kell tartani, ideértve azokat az üléseket is, amelyek során a Parlament a ráruházott költségvetési hatáskört gyakorolja a Szerződés alapján. További plenáris üléseket ezért nem lehet más munkavégzési helyre ütemezni, kizárólagosan csak akkor kerülhet erre sor, amennyiben a Parlament a 12 rendes plenáris ülést Strasbourgban, ahol a székhelye található, adott év során megtartja.

Mindezt az támasztja alá, hogy a Bíróság a 2012. évi ítéletében ${ }^{11}$ kimondta, hogy „noha a Parlament e belső szervezési jogkör alapján meghozhatja a szükséges intézkedéseket a megfelelő múködés és ügymenet biztosítása érdekében, e döntéseknek tiszteletben kell tartaniuk a tagállamok arra vonatkozó hatáskörét, hogy a Parlament rendes plenáris ülésének helyét meghatározzák” ${ }^{12}$ Az EUB a fentebb említett 1997. évi ítélet 29. pontjára a 2012. évi ítéletében is hivatkozik, értelmezését tovább bővítve: „A Bíróság azt a következtetést vonta le, hogy az edinburghi döntést úgy kell értelmezni, hogy az úgy határozza meg a Parlament székhelyét, mint azt a helyet, ahol ezen intézmény tizenkét rendes plenáris ülésszakát egyenletes ütemben meg kell tartani, ideértve azon ülésszakokat, amelyek során a Parlamentnek a szerződésekből eredő költségvetési jogkörét kell gyakorolnia. A Bíróság azt is kimondta, hogy további plenáris ülésszakok tartására tehát csak akkor kerülhet sor valamely más munkavégzési helyen, ha a Parlament tizenkét rendes plenáris ülésszakot tart Strasbourgban, az intézmény székhelyén." ${ }^{13}$ Ezen érvelésre tekintettel a konkrét ügyben a Bíróság megvizsgálta, hogy a Parlament - a Francia Köztársaság állításának megfelelően - megsértette-e az intézmények székhelyéről szóló jegyzőkönyveket azzal, hogy 2012. és 2013. vonatkozásában a 10 - augusztus és október kivételével minden egyes hónapban tartott - havi plenáris ülésszakon kívül két olyan plenáris ülésszakot határozott meg, amely október ugyanazon hetében egyenként két napig tart, és helyt adott a Francia Köztársaság keresetének.

A plenáris ülések megrendezésével kapcsolatos esetjogból adódó, jelen ügyben is releváns bizonytalanságokat az is fokozza, hogy 2018-ban a Francia Köztársaság pert indított az Európai Parlamenttel szemben azt állítva, hogy a Parlament megsértette az EUMSZ 314. cikkét, amikor az EU 2017-es pénzügyi évre szóló éves költségvetésének közös szövegtervezetéről szóló vitáját és az arról szóló szavazást a brüsszeli plenáris ülés napirendjére tűzte. Ebben a perben a Francia Köztársaság négy, az Európai Parlamentnek a 2017-es pénzügyi évre szóló éves költségvetés elfogadására vonatkozó jogi aktusának megsemmisítését kérte, azzal érvelve, hogy a megtámadott jogi aktusok sértik az intézmények székhelyéről szóló fentebb hivatkozott jegyzőkönyvet. A konkrét perben

\footnotetext{
10 Az EUB C-345/95 sz. Francia Köztársaság kontra Európai Parlament ügyében 1997. október 1-jén ítéletének [ECLI:EU:C:1997:450] 24., 25. és 26. pontjai

11 Az EUB C-237/11 és C-238/11 sz. Francia Köztársaság kontra Európai Parlament egyesített ügyekben 2012. december 13-án hozott ítélete [ECLI:EU:C:2012:796]

12 Az EUB C-237/11 és C-238/11 sz. Francia Köztársaság kontra Európai Parlament egyesített ügyekben 2012. december 13-án hozott ítélete [ECLI:EU:C:2012:796] 41. pont.

13 Uo. 40. pont.
}

Európai Tükör 2020/3. 
ugyan a Francia Köztársaság ezen egyetlen jogalapját különböző indokok alapján végül elutasította a Bíróság, ${ }^{14}$ a korábbi ítélkezési gyakorlat során felhozott valamennyi érvet azonban megerősítette. Önmagában az a tény, hogy ilyen perre sor került, jelentős jogi bizonytalansághoz vezetett az unió költségvetésével kapcsolatban.

A fenti döntések azt a mérlegelési lehetőséget vetik fel, hogy bármilyen módon is értelmezzük a jelenlegi távolsági plenáris üléseket, a rendelkezésektől való eltérésnek csak abban az esetben van helye, amennyiben ahhoz a tagállamok hozzájárultak, mivel az edinburghi döntés értelmében Strasbourgban megfelelő rendszerességgel 12 rendes plenáris ülést kell tartani, ennek hiányában további plenáris üléseket a Parlament saját hatáskörében eljárva nem ütemezhet munkavégzési helyre.

A kérdés relevanciáját és időszerűségét elsősorban az adja, hogy a strasbourgi helyszín megszüntetésével kapcsolatos politikai és tagállami szándékok a képviselők körében már most megerősödtek, amire vonatkozóan a francia védekező magatartás következményeivel számolni kell. Clément Beaune francia Európa-ügyi államtitkár már a David Sassolival, a Parlament elnökével (az EP elnöke, az Elnök) folytatott 2020. augusztusi tárgyalása során nyomatékot adott elvárásának arra nézve, hogy a strasbourgi ülések helyreállítására mielőbb, már 2020 szeptemberében sor kerüljön. ${ }^{15}$ Ennek ellenére a Parlament elnökének 2020. szeptember 8-i döntése alapján a plenáris ülést Brüsszelben szervezik meg, elsősorban a strasbourgi régió járványügyi besorolására tekintettel.

\section{A személyes jelenlét mint az Európai Parlament müködésének immanens feltétele}

Az Európai Parlament jelenlegi távmegoldással szervezett ülésezése példa nélkül áll, a távolsági ülésezésre vonatkozóan nem rendelkezik az Eljárási Szabályzat. Az ülés ilyen módon való megrendezésére tehát az Eljárási Szabályzat jelenleg hatályos rendelkezései mellett kerül sor, annyi módosítással, hogy a szavazásra vonatkozóan az Eljárási Szabályzat 22. cikk (2) bekezdése, 25. cikk (4) bekezdése, és 192. cikk (1) bekezdése alkalmazásával az Elnökség (az Európai Parlament szabályszerú múködéséért felelős, az Európai Parlament elnökéből, 14 alelnökéből és öt quaestorból álló szerve) kiegészítette az eddigi szavazási eljárásrendről szóló korábbi, 2004. május 3-án meghozott korábbi határozatát, és bevezetett egyes új szabályokat, amelyek a szavazási rend jelenleg alkalmazandó részleteire vonatkoznak. ${ }^{16} \mathrm{~A}$ távolsági szavazás tehát alapvetően az Eljárási Szabályzat 192. cikke szerinti, az elektronikus szavazatszámláló rendszer igénybevételével végzett voksolásnak minősül. Az ülésezés vonatkozásában pedig az Eljárási Szabályzat hatályos rendelkezései alkalmazandók.

A Parlament tehát mind a mai napig nem módosította az Eljárási Szabályzatot annak érdekében, hogy a rendkívüli helyzetre tekintettel eltérő múködési rendet vezessen be.

Az EUB C-73/17 sz. Francia Köztársaság kontra Európai Parlament ügyében 2018. október 2-án hozott ítélete [ECLI:EU:C:2018:787]

15 https://twitter.com/CBeaune/status/1298304600408297472 (A letöltés dátuma: 2020. 09. 07.)

16 Az Európai Parlament 4/2020 sz. Elnökségi határozata.

Európai Tükör 2020/3. 
Ezzel szemben egy, a jogszabályi hierarchiában az Eljárási Szabályzathoz képest alacsonyabb szintű norma keretében, ${ }^{17}$ az Elnökség mint a Parlament „ülések lebonyolításával kapcsolatos döntések meghozataláért felelős szerve” határozott az Eljárási Szabályzat rendelkezéseivel több ponton szemben álló szavazási eljárásrend technikai részleteiről. A működés egyéb aspektusait pedig teljesen érintetlenül hagyta.

Mindez abból a szempontból is meglepő, hogy az Európai Parlament számára az Eljárási Szabályzat módosítása mindig is prioritást élvezett, és a Parlament törekedett rá, hogy e norma pontosan és haladéktalanul kövesse hatásköre folyamatos bővülésének tendenciáját. $^{18}$

$\mathrm{Az}$ Európai Parlament esetében a személyes, fizikai jelenlét az egész működés immanens, alapvető feltétele és lényegi eleme, mivel az Eljárási Szabályzat minden rendelkezése a képviselő jelenlétét feltételezi. ${ }^{19} \mathrm{~A}$ jelenlét a Parlament müködése során egy jogi tény, amelynek az Eljárási Szabályzatban számos jogkövetkezménye van, sok esetben éppen az adott tevékenység érvényességére vonatkozóan, az Eljárási Szabályzat módosításának hiányában pedig nincs lehetőség a személyes jelenlét követelményétől való eltérésre. Az Eljárási Szabályzat módosítására annak 237. cikke alapján ugyanis - az EUMSZ 232. cikkével is összhangban - csak maga a Parlament jogosult, az összes parlamenti képviselő többségének szavazatával. Az Elnökség pusztán az Eljárási Szabályzat által ráruházott feladatkörökben járhat el, amely jelen esetben az ülés lebonyolítására terjed ki, az Eljárási Szabályzat 25. cikke alapján.

Mindezt a tagállami gyakorlat is alátámasztja. A német Bundestag esetében ugyan a szavazások eredményét elektronikus módon összesítik és hitelesítik, az eljárás nem nyújt lehetőséget a távszavazásra. Ennek megfelelően egy új, 125 a) bekezdéssel egészítették ki a Geschäftsordnung 45. cikkét, amely eredetileg megkövetelte a képviselők felének a jelenlétét annak érdekében, hogy jogilag kötelező döntéseket hozhasson. A módosítás értelmében ezt a követelményt a képviselők egynegyedére csökkentették. ${ }^{20}$

2020. március 14-én a román parlament módosította a belső szabályzatát annak érdekében, hogy a parlamenti munkát „elektronikus eszközök használatával” is végezhessék olyan rendkívüli körülmények fennállása esetén (mint például járványok, természeti katasztrófák, földrengések, terrorcselekmények), amelyek akadályozza a képviselőket a személyes jelenlétben. ${ }^{21}$

Franciaországban mindkét kamara, tehát a Nemzetgyúlés és a Szenátus esetében is követelmény a képviselők személyes jelenléte a szavazásokon és nincsenek távszavazásra vonatkozó rendelkezések. Mindkét kamara vonatkozásában lehetőség van helyettesítéssel szavazni rendkívüli körülmények fennállása esetén, beleértve a vis maiort is. A Nemzetgyűlésben a helyettesítéssel történő szavazásra csak „rendes körülmények” között van lehetőség. A Covid-19-válság miatt azonban a Nemzetgyúlés hozzájárult

\footnotetext{
17 Ennek elsődleges indoka, hogy az Eljárási Szabályzat felhatalmazása alapján és keretei között jár el az Elnökség határozatának meghozatala során (a szerző megjegyzése).

18 Simon Hix - Bjørn Høyland: Empowerment of the European parliament. Annual Review of Political Science, 16. (2013), 1. 171-189.

19 Simon Hix - Tapio Raunio - Roger Scully: An Institutional Theory of Behavior in the European Parliament. Biennial Conference of the European Community Studies Association, 1999.

20 Jonas Schaible: Bundestag soll bereits mit einem Viertel der Mitglieder beschlussfähig sein. Spiegel, 2020.

21 Hotărâre nr. 2 din 14 martie 2020.
} 
az eljárási szabályok módosításához annak érdekében, hogy különleges munkamódszereket vezessen be. ${ }^{22}$

\section{Határozatképesség és küszöbérték, vagyis mit jelent valójában a jelenlét?}

Az Eljárási Szabályzat 178. cikkének rendelkezései szerint az Európai Parlament akkor határozatképes, ha az ülésteremben az összes képviselő egyharmada jelen van, amely a Parlament jelenlegi, 705 fős létszámával kalkulálva 235 főt jelent. Az Eljárási Szabályzat explicit módon fizikai jelenlétet határoz meg e tekintetben.

A 178. cikk értelmezése alapján, amennyiben tehát 235 fő nincs jelen a teremben, 38 képviselő által a szavazás megkezdése előtt benyújtott kérelem alapján az Elnök megállapíthatja, hogy a határozatképesség nem áll fenn. A határozatképesség hiányában pedig a szavazás nem érvényes, amelyből következően az Elnök a szavazást a következő ülés napirendjére túzi. A szabály alapján a határozatképesség fennállásának megállapítását kérő képviselőknek a kérelem benyújtásának időpontjában jelen kell lenniük az ülésteremben, a továbbiakban elhagyhatják az üléstermet. Így ezzel a szabállyal kapcsolatosan a jelenlét értelmezése elsődleges fontosságú. Nemcsak arról van tehát szó, hogy 235 képviselő fizikai jelenléte hiányában a jelenlegi körülmények között érvénytelen a szavazás, hanem a kialakult helyzet egyfajta tautológiából származó paradoxont teremt:

A fent említett határozatképességi kifogás következtében az Elnök megvizsgálni köteles, hogy fennáll-e a határozatképesség, vagyis jelen van-e 235 fő az ülésteremben. Mindez két szempontból is nehézségbe ütközik. Amennyiben nincs jelen 235 fő, az Eljárási Szabályzat jelenleg is hatályos rendelkezései szerint az Elnöknek be kell jelentenie, hogy nem áll fenn határozatképesség, a szavazásra nem kerülhet sor, azt a következő ülés napirendjére kell tűzni.

Amennyiben az Elnök úgy dönt, hogy a távrésztvevőkre is kiterjesztően értelmezi a jelenlét szabályait, vagyis úgy határoz, hogy a határozatképesség szempontjából az ülést otthonról követő képviselőket is figyelembe kell venni, ellenőriznie kell a létszámot. Az Eljárási Szabályzat 178. cikk 3. pontja értelmében azonban erre nem vehető igénybe az elektronikus szavazatszámláló rendszer - amelynek keretei között jelenleg a Parlament múködik a korábbiakban is hivatkozott Elnökségi határozat alapján - a vizsgálatot tehát nem lehet teljesíteni.

Mellesleg amennyiben az Elnök úgy foglal állást, hogy nemcsak a fizikai, de a távrészvétel is jelenlétnek minősül, a fent említett legalább 38 képviselő a fizikai jelenlét hiányában is beadhatja a határozatképességi kifogást. A 38 képviselőben meghatározott küszöbérték ellenőrzésére ugyanis a fent említett 3. pont értelmében kifejezetten használható az elektronikus szavazatszámláló rendszer. A szabályozásnak a második fordulatára tekintettel felvetődő probléma, miszerint a határozatképesség ellenőrzésére viszont nem használható a rendszer, ebben az esetben is gátja marad annak, hogy az ellenőrzést az Elnök valójában lefolytathassa.

Crise du Coronavirus-Covid19: conclusions de la Conférence des Présidents. 2020.

Európai Tükör 2020/3. 
Összességében tehát a jelenleg hatályos szabályozás keretei között nincs jogilag érvényes módja a határozatképesség vizsgálatának az Európai Parlamentben.

A fenti logika követhető nyomon az érvényességi küszöbértékek alkalmazásának vonatkozásában is. A 179. cikk 4. pontja értelmében mind a közepes érvényességi küszöbérték - az összes parlamenti képviselő egytizede, amely egy vagy több képviselőcsoportból vagy egyéni képviselőkből, vagy e két csoportból vegyesen tevődik össze - mind pedig a magas érvényességi küszöbérték - az összes parlamenti képviselö egyötöde, amely egy vagy több képviselőcsoportból vagy egyéni képviselőkből, vagy e két csoportból vegyesen tevődik össze - alkalmazása esetén a számítási módot akként kell alkalmazni, hogy azokat a képviselőket lehet számításba venni, akik a támogató képviselőcsoporthoz tartoznak és fizikailag jelen vannak az ülésteremben.

Amennyiben tehát az Eljárási Szabályzat hatályos rendelkezései alapján, a szabályhoz kötött értelmezés keretében vizsgáljuk a jelenlét szabályait, minden olyan esetben kifogásként lehet hivatkozni a jelenlétre, amikor olyan eljárási aktusra kerül sor a Parlamentben, amely közepes vagy magas küszöbértékhez köthető, és minden ilyen esetben lehetetlenné válik az is, hogy az Elnök a küszöbérték fennállását ellenőrizze. Ilyen eljárások lehetnek többek között a közepes küszöbérték vonatkozásában a Parlament első olvasatát megelőző tárgyalások (71. cikk), amelynek értelmében a tárgyalások megkezdéséről szóló határozatot az érintett kompetens bizottság általi elfogadást követő plenáris ülés kezdetén be kell jelenteni. A plenáris ülésen történt bejelentést követő nap végéig a legalább a közepes érvényességi küszöbértéket elérő számú képviselő vagy képviselőcsoport írásban kérheti, hogy bocsássák szavazásra a tárgyalások megkezdéséről szóló bizottsági határozatot. A Parlament még ugyanezen a plenáris ülésen megtartja az említett szavazást.

Azonos szabályozás vonatkozik az írásbeli választ igénylő nagyobb interpellációk esetére is. Az Eljárási Szabályzat 139. cikkének értelmében írásbeli válasz kézhezvételekor, amennyiben legalább a közepes érvényességi küszöbértéket elérő számú képviselő vagy képviselőcsoport kéri, a nagyobb interpellációt fel kell venni a Parlament végleges napirendtervezetébe, tehát szóbeli vitára kerül sor. Ilyen továbbá a módosítás és vita nélküli eljárás esete a plenáris ülésen (159. cikk), amelynek értelmében amennyiben egy jelentést a bizottságban a tagok kevesebb mint egytizedének ellenszavazatával fogadtak el, azt módosítás nélküli szavazásra tűzik a Parlament napirendtervezetére. A napirendi pontról egyetlen szavazással döntenek, kivéve, ha a végleges napirendtervezet kidolgozását megelőzően legalább a közepes érvényességi küszöbértéket elérő számú képviselő vagy képviselőcsoport írásban kéri, hogy a napirendi pontot módosításra nyissák meg. Ebben az esetben az Elnök a módosítások előterjesztésére határidőt állapít meg.

Hasonlóképpen a magas küszöbérték alkalmazásával kerülhet sor a titkos szavazás kérelmezésére, vagy az ülés félbeszakítására, berekesztésére - legalább a magas érvényességi küszöbértéket elérő számú képviselő vagy képviselőcsoport kérelmére a Parlament döntése alapján az ülés egy vita vagy szavazás során félbeszakítható vagy berekeszthető. Az ilyen javaslatról vagy kérelemről haladéktalanul szavazni kell.

A fentiek tehát kétféle jogkövetkezménnyel járnak. Az egyik, hogy amennyiben közepes vagy magas küszöbértékhez kötött eljárási aktusra kerül sor az Európai Parlamentben, bármely képviselő eljárási szabálysértési kifogást terjeszthet elő. A másik 
oldalról megközelítve pedig a távmúködés elvonja a képviselők azon jogát, hogy e küszöbértékekhez kötött eljárási cselekményt hajtsanak végre.

A jelenlét szabályainak alkalmazása kapcsán fennálló értelmezési visszásságok már jelenleg is tapasztalhatók. Az Eljárási Szabályzat 156. cikk rendelkezései alapján a jelenléti ív tanúsága szerint jelen levő képviselők nevét az ülések jegyzőkönyveibe „jelenlévő"-ként kell rögzíteni. Az Elnök által igazoltan távol lévő képviselők nevét az ülések jegyzőkönyveibe „igazoltan távol lévő”-ként kell rögzíteni. E rendelkezések figyelembevételével teljes a bizonytalanság annak kapcsán, hogy kit kell jelenlévőnek, távol lévőnek, illetve igazoltan távol lévőnek tekinteni az ülések vonatkozásában. A 2020. március 26-i plenáris ülés jegyzőkönyve alapján például 75 képviselő volt jelen az ülésteremben, hárman kimentették távollétüket, amely olyan abszurd szituációt teremtett, hogy több mint 600, igazolatlanul távol lévő képviselő szavazott az aznapi szavazások során. A távrésztvevő és ennek megfelelően távszavazó képviselők tehát valójában nem számítottak résztvevőnek, az Európai Parlament ebből következően pedig úgy nyilvánította magát határozatképesnek, hogy valójában nem volt az.

\section{A távszavazás rendje}

Mint fentebb említettem tehát, a jelenlegi szavazási rendre az Európai Parlament szerint az biztosítja a jogalapot, hogy az Elnökség kiegészítette az eddigi eljárásrendrôl szóló korábbi, 2004. május 3-án meghozott korábbi határozatát és bevezette az elektronikus szavazásról szóló új szabályokat, méghozzá a 2020. március 23-án hozott 4/2020. számú Elnökségi határozat keretében. ${ }^{23}$

Határozatában az Elnökség elsősorban arra hivatkozott, hogy a Covid-19-járvány következtében kialakult közegészségügyi helyzetre tekintettel, számos tagállam különböző utazási korlátozásokat vezetett be, Belgium, Franciaország és Luxemburg pedig olyan kötelező közegészségügyi előírásokat fogadott el, amelyek vonatkoznak az Európai Parlament három munkahelyszínére. Ezenfelül pedig kiemelte, hogy az Eljárási Szabályzatban valamint a szavazásra vonatkozó szabályokról szóló, 2004. május 3-i Elnökségi határozatban ${ }^{24}$ az elektronikus szavazási rendszerrel kapcsolatban megállapított rendelkezések és ezek gyakorlati végrehajtása technikai szinten valamennyi parlamenti képviselő ugyanazon a helyen való fizikai jelenlétét feltételezi, ami azonban a jelen körülmények között nem lehetséges.

A döntés célja tehát az volt, hogy minimálisra csökkenjenek a képviselőket és a személyzetet érintő egészségügyi kockázatok, ugyanakkor biztosított legyen a Parlament képessége arra, hogy alapvető költségvetési tevékenységeit tovább folytassa, és különösen hogy teljes mértékben betölthesse szerepét az uniós szinten szükséges sürgős intézkedések elfogadásában. Emiatt az Elnökség egy olyan alternatív elektronikus szavazási rendszer alkalmazását látta indokoltnak, amely lehetővé teszi a Parlament számára, hogy sürgős szavazásokat tarthasson az egész Európára kiterjedő közegészségügyi vészhelyzettel összefüggésében.

\footnotetext{
23 Bureau Minutes of the extraordinary meeting of Friday, 20 March 2020 from 11:00 to 13:00 hours. 2020.

24 Bureau Minutes of the meeting of Monday, 3 May 2004 from 19.00 to 21.30. 2004.
} 
A szavazásra jelenleg olyan módon került sor, hogy a listát, a szavazólapot, valamint a szavazás kezdő és záró időpontját egy funkcionális postafiókról elküldött e-mail útján küldték meg az egyes képviselők hivatalos postafiókjára. A képviselő vagy annak munkatársa ezt követően a szavazólap papíron történő kitöltésével és aláírásával szavaz, majd hivatalos postafiókjáról elektronikus levélben elküldi az elektronikus formátumban beszkennelt vagy lefényképezett szavazólapjának másolatát, de akár arra is lehetősége van, hogy nyomtató hiányában lerajzolja a szavazólapot, majd azon bejelölve a kívánt indikációt, visszaküldje azt a megadott funkcionális postafiókra.

Az Elnökség fenti határozatának motivációi és az alkalmazott megoldás rugalmassága nyilván mind méltányolandó, azonban komoly visszásságokhoz vezet, mivel nem áll összhangban az Eljárási Szabályzat szavazásra vonatkozó rendelkezéseivel, azonban, mint arra már hivatkoztunk, a jogszabályi hierarchia rendje folytán nyilvánvalóan nem is írja felül őket.

Az Eljárási Szabályzat 187. cikke tartalmazza a szavazásra vonatkozó szabályokat, amely szerint a Parlamentben általában kézfeltartással történik a szavazás, de az Elnök bármikor dönthet úgy, hogy a szavazást elektronikus eszközök segítségével kell megtartani; erre került sor a jelen esetben. A szavazást az Elnök nyitja meg és zárja le. Miután az Elnök megnyitotta a szavazást, senki más nem szólalhat fel addig, ameddig a szavazást lezárásról az Elnök nem rendelkezett. Ezt a rendet azonban a távszavazás időigényes voltára tekintettel a Parlament nem tudja követni, többek között a 2020. március 26-i ülés során a sürgősségi eljárásról szóló szavazás 10:00 és 11:00 óra között zajlott, miközben 10:30-kor Ursula von der Leyen, az Európai Bizottság elnöke szólalt fel, tehát a szavazás megnyitása és lezárása között beszélt. ${ }^{25}$ De hasonlóan a szavazás megnyitása és bezárása között tartott vitát a Parlament a Tanács és a Bizottság részvételével a Schuman-nyilatkozat 70. évfordulójának alkalmából is, 2020. május 14-én. ${ }^{26}$

A távszavazás módszerének vonatkozásában aziránt is kétségek merülnek fel egyébként, hogy a szavazási mód a képviselői statútummal ${ }^{27}$ egyáltalán összhangban áll-e, amely alapján a képviselők egyenként és személyesen szavaznak, ami a jelenlegi rendszer esetében csak egy vélelmezett de nem ellenőrizhető feltétel. További kérdéseket vet fel az is, hogy a távmúködés során sorra kerülő valamennyi szavazásra az Eljárási Szabályzat 163. cikke szerinti sürgősségi eljárás keretén belül kerül sor, mivel a távolsági szavazásról szóló 4/2020 Elnökségi határozat a sürgősség tényéhez köti ennek a szavazási módnak az alkalmazhatóságát. Az ekként szavazásra bocsátott dossziék között, a valóban prioritást élvező költségvetési vagy mentesítési állásfoglalások mellett azonban olyan témákkal is találkozhatunk, mint a daktiloszkópiai adatokra vonatkozó, az Egyesült Királysággal való automatizált adatcsere, a gumiabroncsok címkézése vagy az Európai Unió és a Mauritániai Iszlám Köztársaság közötti halászati partnerségi megállapodás meghosszabbítása. ${ }^{28}$ Joggal vitathatja bárki ezeknek az eljárásoknak a sürgősségét és a járványhelyzet kezelésével összefüggésben álló halaszthatatlanságát,

Agenda Thursday, 26 March 2020. European Parliament.

Agenda Thursday, 14 May 2020. European Parliament.

2005/684/EC, Euratom - Az Európai Parlament határozata (2005. szeptember 28.) az európai parlamenti képviselők statútumának elfogadásáról.

28

Az Európai Parlament 2020. május 13. és 15. napjai között megrendezett ülésnapjain szavazták meg.

Európai Tükör 2020/3. 
márpedig a hivatkozott Elnökségi határozat által adott felhatalmazás a járványkezeléssel összefüggésben álló, sürgősségi esetekre szúkítette a távszavazás hatályát.

\section{A felszólalási jog gyakorlása a távmúködés során}

Gyakorlati tapasztalat, hogy a felszólalási idővel kapcsolatos rendelkezések (171. cikk) igencsak nehezen összeegyeztethetők a távmúködéssel. A felszólalás lehetőségének megadása vonatkozásában az elmúlt ülések nagyfokú változékonyságot mutattak. Egyes esetekben csak azoknak a képviselőknek volt lehetősége a felszólalásra, akik ténylegesen a teremben ültek, máskor a Parlament Elnöke online eszközök segítségével kapcsolt be felszólalókat, tette mindezt anélkül, hogy a politikai kiegyensúlyozottság szabályát betartotta volna a felszólalások vonatkozásában, szembemenve ezzel az Eljárási Szabályzat 171. cikkének rendelkezéseivel, amelynek értelmében a felszólalási idő első részét a képviselőcsoportok között egyenlő arányban kell felosztani, a második részt a képviselőcsoportok között tagjaik összlétszáma arányában osztják el, ezenfelül pedig a vita teljes időtartama alatt, amennyire csak lehetséges az Elnöknek biztosítania kell, hogy az eltérő politikai nézetet valló és különböző tagállamokból származó felszólalók felváltva kapjanak szót.

Ráadásul, az Eljárási Szabályzat egyes jelenlegi rendelkezései, például a kékkártya-rendszerre, illetve az egyperces felszólalásokra (172. cikk) vagy más kiegészítő kérdésekre vonatkozó gyakorlati rendelkezések - mint például, hogy a képviselőknek a helyükről kell beszélniük és az Elnökhöz kell fordulniuk - a gyakorlatban ellehetetlenülnek a távrészvétel esetén. Emiatt ezeket a Parlament nem is alkalmazza jelenleg, ennek következtében pedig nyilvánvalóan szűkül a képviselők vitához való hozzájárulásának lehetősége.

A 2020 októberében a fokozódó járványhelyzetre való tekintettel további új szabályokat vezetett be a Parlament elnöke, amelynek értelmében a képviselők a tagállami EP Kapcsolattartó Irodákból is megtehetik felszólalásukat. A novemberi plenáris ülésre a lehetőség gyakorlatilag kötelezettséggé vált, figyelemmel a zárt körben kiküldött 8/2020. számú elnökségi feljegyzésre, ${ }^{29}$ amelynek értelmében az Elnök 2020. október 27-én úgy határozott, hogy a Parlament irányítószerveinek üléseit, a plenáris ülést, a rendes és rendkívüli bizottsági üléseket, továbbá a frakcióüléseket a továbbiakban csak távolsági részvétellel lehet megtartani, ennek megfelelően pedig a napidíjfizetés alapjául szolgáló központi jelenléti nyilvántartást november hónapra lezárta. A képviselők között nagy felháborodást keltett döntés értelmében tehát a plenáris teremben való bármilyen szintű jelenlét 2020 novemberében megszűnt, a jelenlétre vonatkozó, fentiekben részletezett szabályok teljesen értelmezhetetlenné váltak, a plenáris elvesztette vita jellegét, a felszólalási jog gyakorlásának keretei pedig tovább szúkültek. Az előre meghatározott és kötött felszólalási listára tekintettel a Kapcsolattartó Irodákból felszólaló képviselők többek között nem kérhetnek szót, nem tehetnek ügyrendi javaslatot (195. cikk), és nem élhetnek az Eljárási Szabályzat 173. cikke szerinti személyes nyilatkozat lehetőségével.

A 8/2020. számú elnökségi feljegyzés a cikk írásának időpontjában nem volt elérhető az Európai Parlament Nyilvános dokumentumtárában. 
Amennyiben tehát a tárgyalt napirendi pont során egy képviselő személyére nézve olyan megjegyzést tesz valamely felszólaló, amelyet vissza akar utasítani, erre vonatkozóan a vita során nem élhet az észrevétel, a kijelentés visszautasításának jogával.

\section{Lehetséges jogkövetkezmények és orvosolhatóság}

Az Európai Parlament fentiekben bemutatott, több ponton kifogásolható múködésével összefüggésben levonható következtetés nyilvánvalóan nem az, hogy az intézménynek egyáltalán nem kellene működnie vagy szembemenve a közegészségügyi előírásokkal, meg kellene követelnie, hogy a képviselők megjelenjenek az ülésteremben. Sokkal inkább arról van szó, hogy egy uniós intézmény, amely mindemellett még ellenőrzési jogkörrel is rendelkezik más intézmények felett, nem engedheti meg magának, hogy múködése kifogásolható legyen. Azt még kevésbé engedheti meg magának, hogy aktusaival szemben az arra jogosultak megsemmisítési keresetet (az EUMSZ 263. cikke értelmében) támasszanak azért, mert elmulasztotta megfelelően módosítani a saját múködésével kapcsolatos szabályokat.

Összességében mind az eljárási szabályok megsértésével kapcsolatos kifogások, mind pedig a jogszerû működés helyreállítása terén viszonylag egyszerû megoldások állnak az erre esetlegesen hivatkozni kívánó képviselők rendelkezésére. Az Eljárási Szabályzat megsértésének észlelése esetén bármely képviselő kifogást támaszthat ügyrendi javaslat keretében (195. cikk), legfeljebb egyperces felszólalás során. Természetesen csak ha szót kap, hiszen a változékony gyakorlatra tekintettel ez a lehetőség csak azon képviselők esetében tekinthető adottnak, akik fizikailag is az ülésteremben tartózkodnak a vita idején.

A képviselő ilyen esetben felszólalhat azzal a céllal, hogy felhívja az Elnök figyelmét az Eljárási Szabályzat megsértésére. A képviselőnek először meg kell jelölnie azt a cikket, amelyre hivatkozik. Az Elnök az ügyrendi javaslat tárgyában az eljárási szabályzatnak megfelelően haladéktalanul határozatot hoz, és döntését az ügyrendi javaslatot követően haladéktalanul bejelenti, de kivételesen 24 órára elhalaszthatja. Az Elnök határozatáról nincs szavazás. Következményeként a döntés elhalasztása nem jár a vita elnapolásával. A kérelemnek felfüggesztő hatása tehát nincs.

Az Elnök az ügyet az Alkotmányügyi Bizottsághoz is utalhatja döntése keretében. A 236. cikk értelmében az Elnök megkeresi az Alkotmányügyi Bizottságot, amely dönt arról, hogy módosítás szükséges vagy értelmezés elegendő az Eljárási Szabályzat rendelkezéseinek vonatkozásában. Az értelmezés az alacsony küszöbérték szerinti képviselőszámmal megvitatható, bejelentését követő 24 órás időszakon belül. A kérdést a plenáris ülésen szavazásra kell bocsátani. A szöveget egyszerű többséggel fogadják el, azzal a feltétellel, hogy az összes parlamenti képviselő legalább egyharmada jelen van. Elutasítás esetén az ügyet vissza kell utalni a bizottsághoz. Ennek sincs felfüggesztő hatálya.

Egyébiránt minden képviselő javasolhat módosításokat az Eljárási Szabályzathoz, a módosítások az összes parlamenti képviselő többségének szavazatával fogadhatók el, amint arról az Eljárási Szabályzat 237. cikke rendelkezik. 
Radikálisabb lehetőséget jelent a megsemmisítési kereset. Az EUB az EUMSZ 263. cikk keretében megvizsgálja a jogalkotási aktusok jogszerűségét, valamint az Európai Parlament harmadik személyekre joghatással járó aktusait, amint azt már az EUB 1986. évi Parti écologiste „Les Verts” kontra Európai Parlament ítéletében is megállapította. ${ }^{30}$ A Bíróság hatáskörrel rendelkezik az olyan keresetek tekintetében, amelyeket valamely tagállam vagy az intézmények nyújtanak be. Hozzájuk hasonlóan bármely természetes vagy jogi személy is eljárást indíthat a neki címzett vagy az ôt közvetlenül és személyében érintő jogi aktusok ellen, továbbá az őt közvetlenül érintő olyan rendeleti jellegű jogi aktusok ellen, amelyek nem tartalmaznak végrehajtási intézkedéseket. Az eljárás megindítható hatáskör hiánya és azzal való visszaélés miatt, lényeges eljárási szabályok megsértésére tekintettel, továbbá a Szerződések megsértése vonatkozásában egyaránt, a fentiekben áttekintett jogértések mindegyike a kereset megindíthatóságának alapjául szolgálhat. A valódi veszély tehát abban áll, hogy tekintse csak egyetlen gazdasági társaság érdekeivel ellentétesnek az elmúlt időszakban uniós szinten elfogadott intézkedéseket, ez máris indokot jelenthet arra, hogy eljárási szabálysértésre tekintettel a Bírósághoz forduljon, és adott esetben egyetlen cég példáján felbuzdulva a Parlament perek ezreivel vagy kollektív keresetekkel találja szemben magát, a tagállamok által indítható per esetét nem is említve.

A jogszerű mủködés helyreállítása tekintetében már bonyolultabb a helyzet. Felvetődhet, hogy amikor az első távolsági üzemmódban tartott ülésre sor került - tehát 2020. március 26-án - akkor az Európai Parlamentnek első ízben az Eljárási Szabályzat módosításáról kellett volna szavaznia, annak érdekében, hogy a távolsági múködési üzemmódra vonatkozó rendkívüli szabályokat az Eljárási Szabályzat szintjén bevezesse. $\mathrm{Az}$ a tény, hogy a Parlament először a sürgősségi eljárásról szavazott (163. cikk) önmagában még nem jelentett felhatalmazást arra, hogy olyan új üzemmódot, illetve funkciókat léptessen életbe, amelyek bevezetése kizárólag az Eljárási Szabályzat módosítása révén lett volna lehetséges. Mivel azonban már ez az ülés is a kifogásolható távolsági eljárásban zajlott, felmerülhet, hogy az egyetlen megoldás a Parlament számára, hogy rendes múködésének helyreállását követően az első alkalommal megrendezett plenáris ülés keretében egyetlen jogi aktussal visszamenőlegesen jóváhagyja mindazokat a döntéseket, amelyek elfogadására a távolsági eljárás keretében került sor.

\section{Az Alkotmányügyi Bizottság javaslata az Eljárási Szabályzat módosítására}

Az európai parlamenti képviselők egy hányada - elsősorban a néppárti, Alkotmányjogi Bizottságban és Jogi Bizottságban lévő tagképviselőkről van itt szó - maga is felismerte a távműködés harmadik hónapjára, hogy az Európai Parlament múködése kifogásolható,

Az EUB C-294/83. sz. Parti écologiste „Les Verts” kontra Európai Parlament ügyben 1986. április 23-án hozott ítélete [ECLI:EU:C:1986:166]. Az ügyben az EUB elismerte az Európai Parlament passzív perbeli legitimációját.

Európai Tükör 2020/3. 
és mielőbb szükséges az Eljárási Szabályzat módosítása, valamint a meghozott döntések utólagos jóváhagyása.

Paolo Rangel portugál néppárti politikus egy, az angol jogban ismert úgynevezett „indemnity” aktusát látná lehetségesnek, ami gyakorlatilag egy felmentvényt jelent, amelyet elképzelése szerint az Európai Parlament adna önmagának. Az angol jog az „indemnity" fogalmát kétféle esetre használja. ${ }^{31}$ Alkalmazásának egyik esete, amikor egyfajta kártalanításról, szavatosság nyújtásáról van szó, tehát olyan helyzetben alkalmazzák, amikor állami garanciavállalás és helytállás válik szükségessé valamely kárért, amely gondatlan jogellenes vagy jogszerű magatartásból származik. Ilyen a 2020. március 20-i Coronavirus Bill ${ }^{32}$ által a közegészségügyi intézkedések körében nyújtott „indemnity”, amely kiterjed az egészségügyi gondatlanság okozta károkra, amelyek a közegészségügyi előírások követéséből származhatnak.

Emellett pedig használatos arra az esetre, ha különleges jogrend idején a brit kormány a hatályos jogi normákat megszegve ultra vires jár el, és ebből kifolyólag utólagos parlamenti jóváhagyással jogszerúvé kell tenni a korábbi kormányzati intézkedéseket, meghozott normákat. Ilyen volt az 1920-as Indemnity Act, amely a brit kormány háborús intézkedéseit hagyta jóvá.

$\mathrm{Az}$ „indemnity” egyébként egy sokszor kritizált és keveset használt jogintézmény a brit alkotmányjogban is. A brit fennhatóság alatt 1910 és 1960 között múködő Délafrikai Unió vonatkozásában több ilyen „Indemnity bill”-t fogadtak el, és a veszélyhelyzetre való tekintettel utólagosan jogossá nyilvánítottak számos erőszakos cselekményt, ami azt támasztja alá, hogy egy másféle jogi formulát lenne érdemes választania a Parlamentnek erre az esetre. ${ }^{33}$

Államelméleti szempontból ezenfelül azt is ki kell emelni, hogy a brit Parlament nem a saját döntéseit hagyja jóvá az „indemnity” aktus keretében, hanem a kormányét. A parlamentarizmus logikáját követő rendszerben, a törvényhozó hatalom részéről a végrehajtó hatalom aktusának vonatkozásában hozott felmentvény azonban semmilyen módon sem hozható analógiába az Európai Parlamentben kialakult helyzettel. Ennek ellenére az európai parlamenti képviselők végül ezt a formát választották a jogszerű múködés helyreállítására.

A módosítások szövegszintű kidolgozása az Alkotmányügyi Bizottságban zajlott, a jelentéstevő Gabriele Bischoff 2020. július 10-én terjesztette elő javaslatait. ${ }^{34}$ A jelentés szövege elismeri, hogy a Covid-19-világjárvány által okozott egészségügyi válság rávilágított arra, hogy Eljárási Szabályzata nem rendelkezik minden megfelelő intézkedésről

31 Monrad G. Paulsen - Michael I. Sovern: "Public Policy" in the Conflict of Laws. Columbia Law Review, 56. (1956), 7. 969-1016. Dicey megfogalmazása szerint: „An Act of Indemnity is a restrospective statute with the object to make legal transactions which when they took place were illegal, or to free individuals to whom the statute applies from liability for having broken the law." (A szerző fordításában: $\mathrm{Az}$ „Act of Indemnity” visszamenőleges statútum azzal a céllal, hogy olyan ügyleteket nyilvánítsanak jogszerűvé, amelyek sorra kerülésük időpontjában jogellenesek voltak, vagy hogy mentesítsék az egyéneket, akikre a statútum vonatkozik, a jogsértésből származó felelősség alól.)

32 Coronavirus Act 2020.

33 Adam Sitze: The Impossible Machine: A Genealogy of South Africa's Truth and Reconciliation Commission. University of Michigan Press, 2013.

34 Jelentéstervezet az eljárási szabályzat módosításáról a Parlament rendkívüli körülmények közötti múködésének biztosítása érdekében [2020/2098(REG)]. 
a Parlament rendkívüli körülmények közötti múködésének megkönnyítése érdekében, és előirányozza, hogy a Parlament a módosítások elfogadásával tudomásul veszi az Elnöke és irányító testületei által elfogadott ideiglenes intézkedéseket, egyúttal elismeri, hogy ezek az ideiglenes intézkedések teljes mértékben indokoltak voltak, és biztosították az alkalmazási idejük alatt hozott valamennyi szavazás érvényességét. Ennek megfelelően tehát a módosítások megszavazásával a Parlament utólag elismeri a járványhelyzet alatt meghozott határozatok érvényességét.

A módosítások külön rendelkeznek a rendkívüli körülmények esetéről, mivel erre vonatkozó rendelkezést az Eljárási Szabályzat nem tartalmazott mindezidáig. Ilyen rendkívüli körülmények akkor állnak fenn, ha az Elnök arra a következtetésre jut, hogy biztonsági vagy védelmi okokból, vagy a technikai eszközök hiánya miatt lehetetlen vagy veszélyes, illetve lehetetlen vagy veszélyes lesz a Parlament szokásos eljárásoknak és az elfogadott naptárának megfelelő összehívása. Főszabály szerint ilyen esetben az Elnök az Elnökök Értekezletének egyetértésével határozhat a szükséges intézkedések alkalmazásáról. A határozatnak tartalmaznia kell azt is, hogy melyek azok a tevékenységek, amelyek rendkívüli körülmények fennállása esetén is elengedhetetlenek és sürgősek a Parlament számára. E tevékenységek magukban foglalják a rendkívüli körülményekre, a költségvetési ügyekre, a sürgős jogalkotási eljárásokra vagy a jelentős politikai eseményekre tekintettel meghozandó intézkedéseket. E körön túl egyéb tevékenységet a Parlament tehát nem folytathat, kérdés tehát, hogy elfogadhat-e a Parlament rendkívüli körülmények alatt saját kezdeményezésú jelentéseket, amelyek semmi esetre sem minősülnek sürgős jogalkotási eljárásnak.

Az Elnöknek az Elnökök Értekezlete által jóváhagyott határozatát követően bármely képviselőcsoport vagy legalább az alacsony érvényességi küszöbértéket elérő számú képviselő kérheti, hogy a határozat által érintett intézkedéseket nyújtsák be a Parlamentnek, vita nélküli jóváhagyásra. Amennyiben egy intézkedés nem kapja meg a leadott szavazatok többségét, az a szavazás eredményének bejelentését követően érvényét veszti.

Az Elnök a Parlamenten belüli erőviszonyok zavartalanságát köteles biztosítani rendkívüli körülmények esetén is. Részben ezt a célt szolgálják a távoli részvétel lehetővé tételére vonatkozó intézkedések, amelyek a módosító javaslatok szerint egyaránt alkalmazhatóak a képviselők egy érintett csoportjára vagy valamennyi képviselőre. A javaslat egyértelmúen kimondja, hogy a Parlament eljárásait távolról is lefolytathatja, többek között azáltal, hogy valamennyi képviselő számára lehetővé teszi, hogy bizonyos parlamenti jogait elektronikus úton gyakorolja.

Az ambiciózus módosító javaslat szerint a távolsági üzemmódban a képviselők akadálytalanul kell hogy gyakorolhassák parlamenti megbízatásukat, ideértve különösen a plenáris ülésen és a bizottságokban való felszólaláshoz, a szavazáshoz és a szövegek benyújtásához való jogukat. A távszavazási rendszer lehetővé kell tegye a képviselők számára a rendes szavazást, a név szerinti szavazást és a titkos szavazást egyaránt, a képviselők részvétele a parlamenti vitákban és szavazásokban a Parlament által múködtetett elektronikus eszközök használatával valósul meg. 
A javasolt módosítások méginkább megkérdőjelezhető része, amely kimondja, vannak olyan jogok és gyakorlatok, amelyek a képviselők fizikai jelenléte nélkül megfelelően nem gyakorolhatók, ezeket pedig a távolsági üzemmód esetén az Elnök a távolsági müködés elrendeléséről szóló határozatában „kiigazítja”. Ilyen jogok és gyakorlatok többek között a határozatképesség ellenőrzésére vonatkozó rendelkezések, az ülésen való jelenlét elszámolása, a felszólalási idő felosztása, a napirend - szinte tehát az ülésezés valamennyi aspektusa. A jelenlegi visszásságokra tehát a módosító javaslat nem kínál semmilyen megoldást, egyrészt az Elnök hatáskörébe utalja ennek megoldását, másrészt pedig úgy vetíti előre az ülésezéshez kapcsolódó egyes képviselői jogok módosítását, csorbítását, hogy közben megerősíti: a távolléti rendszerben részt vevő képviselőt azonos jogok illetik azzal, mint aki fizikailag jelen van az ülésteremben.

A módosító javaslatok jelen állapotukban tehát nem kínálnak valódi megoldást a távolsági ülésezés által felvetett problémákra. A távolsági üzemmód technikai megoldásaival kapcsolatban ez nem más, mint egy kívánságlista, amelynek a jelenlegi múködés egyáltalán nem felel meg. A távmüködés által alkalmazhatatlanná váló szabályok alkalmazhatóvá tételére pedig kísérletet sem tesz, ehelyett elnöki hatáskörbe utalja annak megoldását.

Az AFCO bizottság előtt 2020. október 9-én megszavazott szöveg a módosítók fényében nem változott számottevően, tekintettel arra, hogy a jelentéstevő már előzetesen egyeztetett az árnyék-jelentéstevőkkel a szöveg vonatkozásában. Amennyiben azonban a Parlament ezt a javaslatot fogadja el, az a járványhelyzet alatt meghozott döntések érvényessé nyilvánítására is csak abban az esetben kínál megoldást, ha azt egy szabályos, személyes részvétellel megrendezett strasbourgi ülésen fogadják el, és akkor is csak az Eljárási Szabályzat alapján történő megtámadhatóságot orvosolja. A tagállamok jóváhagyása az évi 12 strasbourgi ülés hiányában nem megkerülhető. Az ülésezéssel kapcsolatos egyes részletszabályozáshoz fűzött, távmúködés esetére vonatkozó részletes és speciális módosító javaslatok lennének szükségesek annak érdekében, hogy a javaslat teljes jogbiztonságot teremtsen - ahelyett, hogy ezt a hatáskört is az Elnökre telepítené, ami az erőviszonyok között aránytalanságot eredményez, különösen mivel az elnöki határozathoz a képviselők annak megtámadása esetén sem füzhetnek módosítást. Az a tény pedig, hogy a pandémia elmúlt fél éve során a Parlament nem alakított ki a felszólalással kapcsolatos képviselői jogosultságokat maradéktalanul érvényesítő rendszert, felveti a kérdést, hogy képes lesz-e majd lépést tartani saját Eljárási Szabályzatával a technológiai változások terén, amennyiben a képviselők a plenáris ülésen elfogadják a módosítást.

A frakciók közötti ellentmondások, különösen a szavazás lehetséges formái kapcsán kialakult bizonytalanság miatt a jelentés csupán 2020. december 17-én került az EP plenáris ülése elé. A Parlament a javaslatot 598 támogatás, 58 ellenszavazat és 33 tartózkodás mellett elfogadta. A valódi probléma azonban ezáltal nem hárult el. Az Eljárási Szabályzat módosítására nem személyes részvétellel megrendezett, szabályos strasbourgi ülésen, hanem távszavazási eljárási rendben került sor, és így a Parlament aktusai nem váltak utólagosan érvényessé, hanem azok - akárcsak maga a decemberben megszavazott módosítás - a megsemmisítési kereset általános szabályai szerint továbbra is támadhatók. 


\section{Felhasznált irodalom}

Hix, Simon - Bjørn Høyland: Empowerment of the European parliament. Annual Review of Political Science, 16. (2013), 1. 171-189. DOI: https://doi.org/10.1146/annurev-polisci-032311-110735

Hix, Simon - Tapio Raunio - Roger Scully: An Institutional Theory of Behavior in the European Parliament. Biennial Conference of the European Community Studies Association, 1999.

Paulsen, Monrad G. - Michael I. Sovern: "Public Policy" in the Conflict of Laws. Columbia Law Review, 56. (1956), 7. 969-1016. DOI: https://doi.org/10.2307/1119628

Sitze, Adam: The Impossible Machine: A Genealogy of South Africa's Truth and Reconciliation Commission. University of Michigan Press, 2013. DOI: https://doi.org/10.3998/ mpub. 243251

\section{Internetes források}

Agenda Thursday, 14 May 2020. European Parliament. Elérhető: www.europarl.europa.eu/ doceo/document/OJQ-9-2020-05-14_EN.html (A letöltés dátuma: 2020. 05. 22.)

Agenda Thursday, 26 March 2020. European Parliament. Elérhető: www.europarl. europa.eu/doceo/document/OJQ-9-2020-03-26_EN.html (A letöltés dátuma: 2020. 05. 23.)

Bureau Minutes of the extraordinary meeting of Friday, 20 March 2020 from 11:00 to 13:00 hours. 2020. Elérhető: www.europarl.europa.eu/RegData/organes/bureau/proces_ verbal/2020/03-20/BUR_PV(2020)03-20_EN.pdf (A letöltés dátuma: 2020. 06. 02.)

Bureau Minutes of the meeting of Monday, 3 May 2004 from 19.00 to 21.30. Elérhető: www. europarl.europa.eu/RegData/organes/bureau/proces_verbal/2004/05-03/BUR_ PV(2004)05-03_EN.pdf (A letöltés dátuma: 2020. 06. 02.)

Coronavirus Act 2020. Elérhető: https://services.parliament.uk/Bills/2019-21/coronavirus/documents.html (A letöltés dátuma: 2020. 09. 07.)

Crise du Coronavirus-Covid19: conclusions de la Conférence des Présidents. 2020. Elérhető: www.assemblee-nationale.fr/dyn/actualites-accueil-hub/crise-du-coronavirus-covid19-conclusions-de-la-conference-des-presidents (A letöltés dátuma: 2020. 05. 25.)

https://twitter.com/CBeaune/status/1298304600408297472 (A letöltés dátuma: 2020. 09. 07.)

Az Európai Parlament múködésének központositása révén elérhető uniós költségvetési megtakarítások elemzése. Európai Számvevőszék, 2014. Elérhető: www.eca.europa.eu/Other \%20publications/PL1407_LETTER/PL1407_LETTER_HU.pdf (A letöltés dátuma: 2020. 05. 26.)

Jelentéstervezet az eljárási szabályzat módositásáról a Parlament rendkívüli körülmények közötti múködésének biztosítása érdekében [2020/2098(REG)]. Elérhető: www.europarl.europa.eu/doceo/document/AFCO-PR-654009_HU.pdf (A letöltés dátuma: 2020. 07. 14.) 
Schaible, Jonas: Bundestagsoll bereitsmiteinem ViertelderMitgliederbeschlussfähigsein. Spiegel, 2020. Elérhető: www.spiegel.de/consent-a-?targetUrl=https\%3A\%2F\%2Fwww. spiegel.de\%2Fpolitik\%2Fdeutschland\%2Fcorona-krise-bundestag-soll-bereits-mit-einem-viertel-der-mitglieder-beschlussfaehig-sein-a-1989849b-d666 -4bae-b0c6-58558fdee60d (A letöltés dátuma: 2020. 05. 26.)

\section{Jogforrások}

2005/684/EK, Euratom - Az Európai Parlament határozata (2005. szeptember 28.) az európai parlamenti képviselők statútumának elfogadásáról

Az Európai Unióról szóló szerződés egységes szerkezetbe foglalt változata

Az Európai Unió múködéséről szóló szerződés

Az Európai Parlament Eljárási Szabályzata

Az Európai Parlament 4/2020 sz. Elnökségi határozata

Az Európai Parlament 2004. május 3-i határozata eljárásrendjének részletszabályairól

Az Európai Parlament 2020. október 29-én kelt 8/2020. számú elnökségi feljegyzése

Az Európai Unió Bíróságának esetjoga

Az EUB C12/92. sz. Edmond Huygen és társai elleni büntetőeljárás, előzetes döntéshozatal iránti kérelem: Hof van Cassatie - Belgium ügyben 1993. december 7-én hozott ítélete [ECLI:EU:C:1993:914]

Az EUB C-237/11 és C-238/11 sz. Francia Köztársaság kontra Európai Parlament egyesített ügyekben 2012. december 13-án hozott ítélete [ECLI:EU:C:2012:796]

Az EUB C-73/17 sz. Francia Köztársaság kontra Európai Parlament ügyében 2018. október 2-án hozott ítélete [ECLI:EU:C:2018:787]

Az EUB C-294/83. sz. Parti écologiste „Les Verts” kontra Európai Parlament ügyben 1986. április 23-án hozott ítélete [ECLI:EU:C:1986:166]

Hotărâre nr. 2 din 14 martie 2020. Elérhető: http://legislatie.just.ro/Public/DetaliiDocument/223817 (A letöltés dátuma: 2020. 05. 25.)

Európai Tükör 2020/3. 